\title{
Constraining the conditions of rare earth element mineralization in the Bear Lodge Alkaline Complex, Wyoming: A fluid inclusion study
}

DANIELLE A. OLINGER ${ }^{1 *}$, ALLEN K. ANDERSEN ${ }^{2}$ AND MitCHELl M. BENNETT ${ }^{1}$

${ }^{1}$ U.S. Geological Survey, Denver, CO 80225

dolinger@usgs.gov, mbennett@usgs.gov

${ }^{2}$ U.S. Geological Survey, Spokane, WA 99201

akandersen@usgs.gov

The Eocene Bear Lodge Alkaline Complex includes a carbonatite-hosted rare earth element deposit. Fluorite veins and smoky quartz veins related to carbonatite and alkaline silicate intrusions occur in the mid-to-distal areas of the complex. The fluorite dominant veins contain two generations of fluorite: early, inclusion-rich and a late, inclusion-poor. Primary fluid inclusion assemblages (FIA) are aligned with growth bands in the smoky quartz and some distal fluorite samples. The FIA are either liquid-vapor or liquid-vaporsolid(s). Nahcolite, identified by Raman spectroscopy, is the most common solid phase present: celestine, barite, strontianite, and calcite are also present in some inclusions. Carbon dioxide was detected in about half of the inclusion vapor bubbles and sulfate was identified in the aqueous phase of most inclusions. Preliminary microthermometry measurements have been completed. Eutectic temperatures

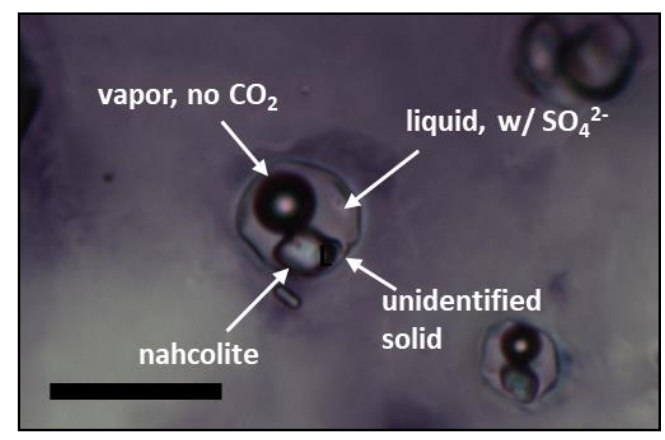

Figure 1: Fluid inclusion assemblage in inclusion-poor fluorite. Scale bar is $56 \mu \mathrm{m}$.

are $-30 \pm 3{ }^{\circ} \mathrm{C}$ suggesting a system more diverse than $\mathrm{H}_{2} \mathrm{O}$ $\mathrm{NaCl}$ or $\mathrm{H}_{2} \mathrm{O}-\mathrm{KCl}$. Ice melt temperatures are observed from -9.4 to $-21.3{ }^{\circ} \mathrm{C}$ with maximum calculated salities ranging from 13 to $23 \% \mathrm{NaCl}$ equivalent. Clathrate melting temperatures range from 5.6 to $19.7^{\circ} \mathrm{C}$. 